\title{
After the Lost Decades: Rethinking Africa's development from a Developmental State Perspective
}

\section{Costa Hofisi}

\author{
North-West University, Department of Public Administration, \\ email: costa.hofisi@nwu.ac.za / berverlycolds279@gmail.com
}

\section{Doi:10.5901/mjss.2013.v4n11p423}

\begin{abstract}
This article rekindles the debate on the developmental state for the consolidation of gains in the growth of Africa's economies in recent years. That Africa is unlikely to meet any of the 'poverty-busting goals' nor the United Nations benchmarks on education, health, and women's empowerment is the rationale behind the argument for the developmental state. This article argues that African does not need some delusional epistemological or ontological revolution of paradigms but Africa needs a new cause that suggests practical and pragmatic approaches to both economics and politics. Highlighting the Chinese experience, the article demonstrates that a declared commitment to poverty eradication is not an end in itself, rather, it must be a means to an end, coupled with the promotion and sustenance of development and a far reaching transformation of society's economic, social, political and cultural structure which is typical of a developmental state.
\end{abstract}

Keywords: developmental state, poverty alleviation, development, Africa

\section{Introduction}

There can never be a more noble call than a call for Africa to strategically position itself in the $21^{\text {st }}$ century given the vagaries of globalization and there can never be a more opportune time than now. The fact that Africa is unlikely to meet any of the 'poverty-busting goals' - nor the benchmarks on education, health, and women's empowerment is the rationale behind such a call. What African needs is not a rhetoric of development but the practice of development. Africa does not need some delusional epistemological or ontological revolution of paradigms perse but Africa needs a new cause that suggests practical and pragmatic approaches to both economics and politics. It is against this background that this paper argues that what the post-colonial African state need today as it seeks to position itself in the twenty first Century is a 'Developmental State'. While this paper does not necessarily advocate a look east policy, it, however, acknowledges the stunning developmental progress realized by the East in the past decades and asserts that Africa can draw lessons from the East.

While endemic, pervasive and persistent poverty continues to disfigure the face of the African continent and compromise the dignity of the African people, the eastern Countries particularly the Asian Tigers and China have seen decades of tremendous economic growth that have catapulted their masses from the doldrums of poverty. Most African economies have been shrinking and regressing despite a declared commitment to do the opposite and decades of preoccupation with development.

A state is developmental when it is has established as its principle of legitimacy its ability not only to promote but also sustain development and a far reaching transformation of society's economic, social, political and cultural structure (Mkandawire: 2001). China has set an example internationally for reducing poverty, raising hundreds of millions of people out of poverty in 20 years. China's celebrated success in rural poverty alleviation was premised on a powerful vision of a developmental State. After carrying out a well thought out, comprehensive and coherent poverty alleviation strategy the number of persons living in poverty in China was reduced from 250 million at the start of its reform process in 1978, to 80 million by the end of 1993 and to 29.27 million in 2001.

While China has achieved such a feat, the efficient and effective alignment, integration, and coordination of policy actions has been and continues to be one of the major challenges that has frustrated post-colonial African governments in their quest to eradicate poverty and provide basic services to all its people as well as progressively advance the quality of life and opportunities for all Africans.

The 'policy crisis', therefore, over the last decade has been manifest in a range of Acts, policies, strategies, development planning instruments, integration mechanisms and structures which did not necessarily yield meaningful results on the ground. Ideally a plethora of these policies coupled with their noble objectives would have been foundation 
stones in the fight against poverty, if they were premised on efficiency, effectiveness, equitability and sustainability of governmental resource allocation all of which epitomize a developmental state. Therefore, this paper posits that an African policy on development is not supposed to and cannot be a ruling political party slogan rather it must be a meaningful and purposeful statement of intent with a coherent, consistent and commensurate set of well thought out and achievable objectives and instruments deliberately seeking to ameliorate a properly diagnosed policy problem. A policy document does not emanate from a 'black box' and neither does the policy process have to be sacrificed on the altar of political expediency as is often the case with many policies in Africa.

Against this background, it is important to note that a developmental policy for Africa must be predicated on a vision to transform the economy and society at large and while emphasizing on deployment of resources for development which is not the case with many African States. The Chinese government has carried out a full-scale fight against poverty in an organized and planned manner over the past two decades, having amassed human, material and financial strength and mobilized all sectors of society for this purpose. While increasing investment to improve production and living conditions in poverty-stricken areas, China has also paid more attention to ecological and environmental protection and for sustainable development. This was all attributable to broad participation in subsequent reform driven economic growth and a well funded national poverty reduction program.

It is against this background that this paper observes that in order to fight poverty in Africa the vitality of the need for a comprehensive all encompassing and multifaceted national strategy powered by a sublime vision of a typical developmental state can never be overemphasized otherwise the fight against poverty will not only fizzle into thin air but will be reduced to moribund efforts and 'paper tigers'. Currently, what poverty is to Africa seems to be like what spots are to a leopard. Endemic, pervasive and persistent poverty continues to disfigure the face of the continent and compromise the dignity of the African people. Africa is a continent not only of great potential but of great promise and hope as well due to the abundance of human and natural resources. However the socio-economic and political conditions on the ground portray post colonial Africa as a continent of despair, war, disease, poverty and hunger.

Therefore, a triumph over poverty in and for Africa is not necessarily a symbol of goodwill nor is it an end in itself rather it is a fundamental and monumental act of justice as well as the protection of fundamental and inalienable human rights, including the right to self esteem, the right to a decent life and dignity. Thus for Africa, the dignity of its people cannot be said to be fully restored and it will always be a negation of fundamental human rights as long as the African masses remain trapped in the vicious circle of poverty. It is against the backdrop of such observations that this paper reflects on the Chinese model to glean for opportunities for replication in the African context.

That Africa remains not only poor but unevenly developed not only racially but geographically cannot be contested. This is manifest in the dichotomy between the rural and the urban as well as the 'blacks' and the 'whites'. While development ideally is supposed to be organized and not disorganized African development has always been dominated by capitalism instead of zeroing in on development of the underdeveloped. The majority of the rural populace not only in Africa but in third world countries in general and African countries in particular remain trapped in the vicious cycle of poverty if not abject poverty which in some cases is demeaning, dehumanizing, and grueling. It is against this background that most post colonial governments in Africa came up with a plethora of policies and strategies to address the poverty pandemic. However, there appears to be lack of policy clarity, coherence, and alignment prompting some authors to assert that Africa still needs a strategy to combat poverty as if nothing has been done as yet.

\section{The African State and development in perspective}

Without being 'pessimistic in diagnosis' and 'optimistic in prescription' one can still argue that the African state has failed to develop at least for the past decades despite its declared commitment and preoccupation with development. The goal of development has been an elusive one for Africa and the prospects of meeting the millennium development goals get dim as the year 2015 draws near.

The United Nations called for an emergency summit in the light of the inevitable failure by the continent to meet the millennium development goals one of which is poverty alleviation. The World Bank (2006:x) observes that reducing poverty in Africa might appear to be an "exclusive, even quixotic goal", by all measures poverty in Africa as a whole has increased and deepened and the prospect of meeting the millennium development goals seem to be receding. In fact the number of poor in sub Saharan Africa is expected to rise from 314 million in 2001 to 366 million in 2015. In the definition of poverty it is important to note that theory distinguishes between "relative poverty" and "absolute poverty". While relative poverty suggests that People are judged to be poor if they are poor in comparison to those around them-implying that the meaning of poverty changes from time to time and place to place (Mkandawire 1999:30), absolute poverty implies an 
objective, even scientific notion (Alcock 2006:68). On the other hand the basic needs approach emphasizes lack of basic needs such as shelter, food and clothing as manifestations of poverty which however is a negation of the fact that needs could be dynamic changing from time to time and place to place.

Authoritarianism, political instability, ethnic and religious conflicts, and civil wars have perpetuated the state of underdevelopment and poverty in Africa. Political crises have continued to plague most African countries since independence. Due to the crisis in Darfur, civil wars in Liberia in the 1990s, the Ivory Coast in the 2000s Angola for most of its independence period Nigeria in the 1960s and the crisis in the horn of Africa, the genocide in Rwanda that claimed over half a million lives the continent still remains trapped in the vicious circle of underdevelopment. "Failed states" as seen at one point in Liberia and Somalia have manifested political crises while mal-governance, colonialization and personalization of the state and national resources by the political elite continue to be impediments to the successful development of the African Continent. Such a plethora of internal factors coupled with the non-accountability of public officials, a lack of transparency in decision-making and the vagaries of globalisation have all contributed to the socioeconomic malaise plaguing Africa.

Moreover, Ake (1997:429) laments that with the transnationalisation of more and more issues especially economic activities more decisions which are important for our lives are made in distant places often anonymously by agents we don't know. It is against this background that the call for a developmental orientation of the African State is made.

Chambua (1994:16) asserts that the first decades of independence have seen a period of endless experimentation with various policies and strategies aimed at bringing about socio-economic development in least developed countries (LDCS). He further argues that irrespective of the particular paradigm/school of thought that has informed particular polices and strategies pursued by (LDCS) the end result has been the same leading some social scientists to conclude that development theories are in a crisis or state of bankruptcy, hence the urgent call for a developmental State.

Moreover, Lancaster (1999) laments why Africa has failed to develop, after four decades and billions of dollars in foreign aid. She laments that despite the natural resources including oil, diamonds, gold, other base minerals, agricultural and tourism potential, coupled with a declared commitment to development and indubitable talent of its people Africa has failed to develop.

\section{Towards a Developmental State}

It is against the aforementioned background of the African State and development that the call for a developmental State for Africa is made. The arguments against the developmental state in Africa are 'not firmly founded either in African historical experience or in the trajectories of the more successful developmental states' (Mkandawire 2001:2) hence the call for a developmental orientation of the African State which inevitably capacitates the State not only to formulate policies but implement them in an effective and efficient manner.

Authors distinguish between ideological and structural components of developmental states, while the former implies a 'developmentalist' state pursuing economic development the latter emphasizes institutional, technical, administrative and political capacity for efficient and effective policy implementation. A developmental state may be simply defined as a state whose primary goal and commitment is the accomplishment of developmental goals, while development is defined as a far reaching transformation of society's economic, social and political structure, of the dominant organization of production, distribution and consumption (Baran 1957:3).

While the developmental orientation of a state is dynamic and not static, such a state envisions development as its ultimate goal. Mkandawire (2001:2) succinctly posits that the definition of a developmental state however runs the "risk of being tautological since it is deductively drawn from the performance of an economy".

A state is also said to be developmental when "it establishes as its principle of legitimacy its ability to promote sustained development, understanding by development the steady high rates of economic growth and structural change in the productive system, both domestically and its relationship to the international economy" (Catsells, 1992:55). Such a state has a "developing economy and equates economic success to state strength while measuring the latter by the presumed outcomes of its policies" (Mukandawire 2001:2).

Moreover, a developmental State implies a State whose vision, leadership and capacity result in a positive transformation of a society within a 'condensed' period of time Johnson (1982), Deyo (1987) and Evans (1995).These definitions of a developmental state potray it as a State with a leadership genuinely committed to the accomplishment of developmental goals. Thus, a developmental state does not sacrifice policies, programs and projects on the alter of political expediency rather it is informed and inspired by patriotism and nationalism and powered by a sublime vision of championing development. Implied in the notion of a developmental state, therefore, is prioritizing or putting national 
development first and personal aggrandizement last.

Therefore, a developmental state for Africa, goes beyond a 'parasitical state', 'kloptocratic state' 'overextended state', 'crony state', 'overextended state', 'patrimonial state', 'predatory state' (Mkandawire 2001:1) and neither is it supposed to be a dependent state. It must be one that has established as its principle of legitimacy its ability not only to promote but also sustain development and a far reaching transformation of society's economic, social, political and cultural structure. Such a State will put national development first and political expediency last.

\section{The Chinese experience: lessons for Africa}

After the death of Mao Tse Tung, Den Xiaoping came up with what he termed 'four modernizations' introduced first by Zhou Enlai in 1975. These were the modernization of science, technology, agriculture and defence. These modernizations coupled with the 'help-the-poor program' were the foundation stones upon which the unprecedented development which China enjoyed was built. After the implementation of the aid-the-poor program, 200 million people had food and clothing problems solved while the impoverishment rate tumbled from $30.7 \%$ close to three percent. The white paper on rural China's poverty reduction program observed that by the end of 2000, 95.5 percent of administrative villages had electricity in poverty stricken areas while 89 percent were accessible by road, 69 percent had postal services, $67,7 \%$ could be reached by telephone and at least 77.25 million had dinking water.

The Chinese government came up with what they called the 'Help the Poor Program' which largely underwent three phases namely: 'structural reform promotes poverty relief' (1978-1985), 'large scale development-oriented poverty relief drive' (1986-1993) and 'tackling key problems of poverty relief' (1994-2000).

At the beginning of the first stage the number of the poverty stricken population according to the poverty standard designated by the Chinese government was 250 million, thus constituting 30.7 percent of the rural population. This phase had a three pronged approach which saw reforms which led to a rise in the price of agricultural products (source of income for the rural poor), transformation of the land management system from a collective one to the house contract responsibility system, thereby, raising productivity, and creation of employment in non-agricultural sectors (thus generating income for the rural poor.)

All of these measures in the first phase saw grain output per capita increase by 14 percent, cotton by $73,9 \%$, meat by $87 \%$, net income by over 3005 , oil bearing crops by $174,6 \%$, the rural poor with food and clothes problems decreased from 250 million to 125 million thus $14.8 \%$ of the rural poor while on average the number of the rural poor shrunk annually by 17.86 million (white paper on rural China's poverty reduction program).

The second phase saw uneven development between poverty stricken areas and coastal advanced areas due to geographical, economic, social historical and natural causes such that disparities became marked. It was against this background that the Chinese government sought to reinforce poverty relief through the reformation of 'traditional relief type approach' and the advancement of developmental orientation to the poverty relief policy. This comprehensive transformation program saw allocation of special funds, formulation of special policies and the setting up of help the poor work units.

Due to this historical period of transformation, only 8.75 down from $14.8 \%$ was the proportion of the poverty stricken rural poor, thus the number of the poverty-stricken dropped from 125 million to 80 million with an annual decrease of 6.4 million, while the net income per peasant in 'poverty stricken counties' leaped from 206 yuan in 1986 to 483, 7 yuan in 1993 according to the white paper on rural China's poverty reduction program.

A seven year 'priority poverty alleviation program' was promulgated and implemented under the third phase which sought to tackle key problems of poverty relief from 1994 to the year 2000.The white paper on rural China's poverty reduction program dubbed it 'the first action program for development-oriented poverty reduction with clear and definite objectives, targets, measures and a time limit'. This program emphasized concentration on human, material and financial resources and mobilization of all walks of life for the solution to clothing and food problems for the rural needy. For three consecutive years from 1997-1999, food and clothing needs for eighty million a year were met while the basic objectives of the seven year priority poverty alleviation program had been met.

China's celebrated success in rural poverty alleviation was premised on a powerful vision of a developmental State. Ideally, a developmental state has a vision to transform the economy and society at large and emphasizes on deployment of resources for development which is not the case with many African States.

The World Bank, (2001: 8) asserts that China is widely recognized for its achievements in reducing absolute poverty since the adoption of broad program of rural economic reforms beginning in 1978,Rural poverty declined from roughly 260 million poor people to 42 million in 1998. This was all attributable to broad participation in subsequent reform 
driven economic growth and a well funded national poverty reduction program.

The state council's leading group for poverty reduction was established in 1986 to provide coherence to many poverty reduction initiatives and expedite economic development. Coordinating more than US\$2 billion in annual funding to poverty reduction, the funding was organized under China's 8-7 poverty reduction plan established by the LGPP in 1994 to overcome poverty (absolute) in nationally designated 592 poor counties.

The Chinese experience demonstrates the need for African Governments to do less harm to the poor by reducing the explicit and implicit taxes they face by setting the procurement price closer to the market price. This has got the trickle down effects of boosting disposable income to the power while increasing productivity from the same. Moreover, the pattern of growth for the Chinese carries a lesson that since so much of poverty in developing countries is found in rural areas agricultural growth plays a pivotal role in poverty reduction. Since the majority of Africans derive their livelihoods from agriculture the promotion of agricultural growth in particular and rural development in general is vital for pro-poor growth for Africa. The concept of pro-poor development areas and identification of poverty pockets carries (China's poor area development programs) a crucial lesson for Africa.Macroeconomic stability (avoidance of inflationary shocks) is crucial for poverty reduction from the Chinese experience. Macroeconomic instability coupled with inflationary shocks erodes the value of real incomes that accrue to the poor.

China's poverty reduction program reflects a comprehensive, planned, responsive flexible program deliberately targeting the poor. It demonstrates a high level of political will and commitment to pro-poor growth; these are critical lessons for Africa in its quest to alleviate poverty. The establishment of poverty counties/pockets was a manifestation of a deliberate policy action meant to deal with a properly diagnosed policy problem.

The geographic and sectoral pattern and poverty pockets specific and favourable policies from the Chinese experience reflect critical lessons to be learnt in the pursuit of pro-poor growth since many programs are pursued in the name of pro-poor growth yet in reality they are meant to gain cheap political mileage.

However, there are wrong lessons to be learnt from the Chinese experience since aggregate economic growth was emanating more from sources that accrue more benefit to the rich and less to the poor. Moreover, the Chinese experience has been labeled 'the even progress against poverty'. It is therefore important for Africa to pursue pro-poor growth that does not necessarily 'equalize poverty' nor widen the income gap between the rich and the poor as reflected by the Chinese experience to some extent.

Half the reduction occurred in the first half of the 1980s, and the decline was not continuous thereafter, with the late 1980s and late 1990s periods saw some set-backs for China's poor. This trend of inequality in poverty alleviation is a lesson to be learnt that economic growth at national level must translate to pro-poor growth, otherwise it will only serve to widen the gap between the rich and the poor.

China's experience also suggests that poverty reduction occurs only when it is a high priority for decision makers and when they focus on institutional, technical, economic and social changes as pre-requisites. Thus political will and commitment, leadership and political support coupled with institutional, technical, administrative and political capacity for efficient and effective policy implementation tend to be pivotal in successful poverty alleviation.

\section{Conclusion}

China's poverty reduction program reflects a comprehensive, planned, responsive flexible program deliberately targeting the poor. It demonstrates a high level of political will and commitment to pro-poor growth; these are critical lessons for Africa in its quest to alleviate poverty. The establishment of poverty counties/pockets was a manifestation of a deliberate policy action meant to deal with a properly diagnosed policy problem.

The geographic and sectoral pattern and poverty pockets specific and favourable policies from the Chinese experience reflect critical lessons to be learnt in the pursuit of pro-poor growth since many programs are pursued in the name of pro-poor growth yet in reality they are meant to gain cheap political mileage. Moreover, the Chinese experience demonstrates that the trickle-down theory in development is a myth in Africa propagated by mainstream western economists. Therefore, Africa needs pro-poor policies deliberately and directly targeting the poor. One can learn from the Chinese experience that poor area development programs based on the identification of poverty pockets is crucial for pro-poor growth.

Since the majority of the poor are located in rural areas in many developing countries Africa must learn from the Chinese that the promotion of agricultural growth in particular and rural development in general is critical for pro-poor growth. The Chinese experience also demonstrates that a declared commitment to poverty eradication is not an end in itself rather it must be a means to an end coupled with the promotion and sustenance of development and a far reaching 
transformation of society's economic, social, political and cultural structure which is typical of a developmental state.

\section{References}

Brocckelsby, M.A. and Holland. 1998. Participatory Poverty Assessments and Public Services: Key Messages from the Poor. Report commissioned for the social Development Division, Department for International Development.

Cerioli, A and Zani, S. 1990. A Fuzzy Approach to the measurement of Poverty. In Conceptualizing Poverty for Social Development in the Eastern Cape, Unpublished paper

Chambers, R. 1983, Rural Development, Putting the Last First. Longman, England.

Galbraith, JK, 1970, The Affinent Society, Harmondsworth, Middlesex: Pelican

Edwards, C. 2003. Baseline and Constraints Paper. Report prepared for the PGDP process released in January 2003

Johnson, S.1993. The Earth Summit: The United Nations Conference on Environment and Development. London: Graham and Trotman.

Kurien, C, T, 1983.Poverty, Planning and social transformation in Chambers, Rural Development, Putting the Last First, England: Longman.

Mjedo. I. C. 1999. Mkandawire, poverty and macroeconomic management in Malawi, Sapes books, Harare.

Sen, A.K (1976). Poverty: An Ordinal Approach to Measurement.Econometrica 44 (2):219-231

Sen, A.K. (1983). Poor, Relatively Speaking. Oxford Economic Papers 35(2):153-169

Saunders (1993). Putting the history of white poverty in South Africa on the agenda. South African Historical Journal 28:242-248

Walt, S.V.D.Conceptualising Poverty for Social Development in the Eastern Cape, Unpublished

World Bank. 2002. Understanding Poverty. Available online: http://www.world bank.org/poverty/mission/up1.htm.

World Bank. 2000. World Development Report, the World Bank: Washington D.C. 